\title{
Temperature-mediated outbreak dynamics of the invasive bryozoan Membranipora membranacea in Nova Scotian kelp beds
}

\author{
Robert E. Scheibling ${ }^{1, *}$, Patrick Gagnon ${ }^{1,2}$ \\ ${ }^{1}$ Department of Biology, Dalhousie University, Halifax, Nova Scotia B3H 4J1, Canada
}

${ }^{2}$ Present address: Ocean Sciences Centre, Memorial University of Newfoundland, St. John's, Newfoundland A1C 5S7, Canada

\begin{abstract}
We used underwater videography to examine seasonal and interannual patterns in the cover (on kelp) of the encrusting epiphytic bryozoan Membranipora membranacea, and associated changes in the structure and abundance of native kelp (Saccharina longicruris) populations, at 2 sites on the Atlantic coast of Nova Scotia and over 4 to $11 \mathrm{yr}$ since initial introduction of this invasive species around 1992. We show that (1) changes in the cover of $M$. membranacea on kelp, and in the cover of kelp on the seabed, are reciprocal and seasonal; (2) thermal history during the summer/fall period of bryozoan colony growth explains a large proportion $(83 \%)$ of the interannual variation in peak cover of M. membranacea on kelp; and (3) annual decreases in kelp cover and blade size are related to the degree of infestation by $M$. membranacea, and not to wave action alone. Particularly severe outbreaks of M. membranacea, resulting in extensive defoliation of kelp beds, occurred in 1993, 1997 and 1999. Our field observations indicate that recurrent seasonal outbreaks of this invasive bryozoan can have a devastating effect on native kelp populations in Nova Scotia, which, in turn, facilitates the establishment and growth of the invasive green alga Codium fragile ssp. fragile.
\end{abstract}

KEY WORDS: Invasive species $\cdot$ Kelp beds $\cdot$ Population outbreaks - Thermal history · Wave action - Community organization - Membranipora membranacea - Saccharina longicruris

Resale or republication not permitted without written consent of the publisher

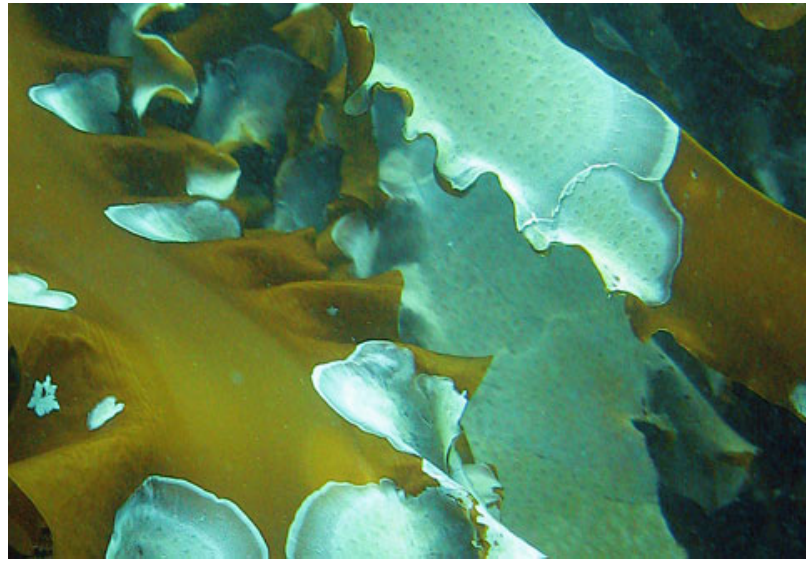

The epiphytic bryozoan Membranipora membranacea encrusting blades of kelp Saccharina longicruris in Nova Scotia

Photo: Robert Scheibling

\section{INTRODUCTION}

Marine ecosystems worldwide are impacted by a high and accelerating rate of human-mediated species introductions (Carlton \& Geller 1993, Carlton 1996, Ruiz et al. 2000, Bax et al. 2003). Our ability to predict, assess, and mitigate effects of introduced species on recipient ecosystems is inherently difficult for various reasons: (1) knowledge of the trajectory of an ecosystem prior to invasion, and of variation in behavior, physiology and population dynamics of invasive spe- 
cies across their introduced range, generally is lacking or incomplete; (2) patterns and mechanisms of invasion often are poorly understood and may vary with spatial and temporal scale; and (3) geographic and taxonomic biases in invasion ecology can impede detection of species-specific invasion mechanisms (Carlton 1999, With 2002, Bruno et al. 2004, Stachowicz \& Byrnes 2006, Pysek et al. 2008).

Historically, the rocky subtidal ecosystem in Atlantic Nova Scotia and the Gulf of Maine (USA) has alternated between 2 community states, kelp beds and urchin barrens (Miller 1985, Scheibling 1986, Harris \& Tyrell 2001, Lauzon-Guay et al. 2009). In the 1990s, synergistic interactions between 2 introduced species, an epiphytic bryozoan Membranipora membranacea and an invasive green alga Codium fragile ssp. fragile (formerly C. fragile ssp. tomentosoides; Provan et al. 2008; hereafter C. fragile) resulted in displacement of native kelps throughout this region (Chapman et al. 2002, Levin et al. 2002, Scheibling \& Gagnon 2006). Given the wealth of ecological information on the structure and functioning of this ecosystem, obtained over the past 4 decades, these events provide a rare opportunity to examine the pattern and process of invasion and the potential of introduced species to trigger an ecosystem phase shift (Chapman et al. 2002).

Membranipora membranacea, native to the North Pacific (Schwaninger 2008), was first detected in the Northwest Atlantic in the Gulf of Maine in 1987, presumably having been introduced from Europe via ballast water (Lambert et al. 1992), and was first reported on the Atlantic coast of Nova Scotia in 1992 (Scheibling et al. 1999). Throughout this region, heavy encrustations of the bryozoan have precipitated marked declines in canopy-forming kelps (Scheibling et al. 1999, Chapman et al. 2002). These defoliation events, in turn, have facilitated the establishment and spread of Codium fragile, which typically is inhibited by dense stands of native kelp (Levin et al. 2002, Scheibling \& Gagnon 2006). Colonies of M. membranacea may cause kelp blades to become brittle (Dixon et al. 1981) and increase their susceptibility to breakage by wave forces during storms (Lambert et al. 1992, Scheibling et al. 1999). This suggests that the extent of kelp defoliation should increase with epiphytic cover of M. membranacea and wave energy.

Short-term studies of recruitment, growth, and abundance of Membranipora membranacea on kelp in Nova Scotia and the Gulf of Maine have provided some insights into seasonal and interannual patterns of bryozoan abundance. For example, Saunders \& Metaxas (2007, 2008) found that settlement of $M$. membranacea peaked in the fall over 2 consecutive years, but occurred earlier and recruits were more abundant following the warmer winter. Measures of peak cover of M. membra- nacea range from $<30$ to $>90 \%$, depending on the year and location (Berman et al. 1992, Lambert et al. 1992, Harris \& Tyrell 2001, Saier \& Chapman 2004, Saunders \& Metaxas 2008). The lack of quantitative studies at broader spatial and temporal scales, however, limits our understanding of the dynamics of bryozoan outbreaks and their effect on kelp beds and the potential role of ocean climate in mediating these events.

In the present study, we examined seasonal and interannual patterns in the cover of Membranipora membranacea on kelp, and associated changes in the structure and abundance of kelp populations, at 2 sites on the Atlantic coast of Nova Scotia. We show that the outbreak dynamics of $M$. membranacea on a decadal time scale strongly relates to thermal history and that the extent of kelp defoliation depends on the severity of infestation. Contrary to our expectation, however, we did not detect a relationship between wave height and kelp declines in late fall, when the abundance of the invasive bryozoan is greatest.

\section{MATERIALS AND METHODS}

Study areas. Our study was conducted at 2 sites differing in wave exposure and kelp-bed structure on the Atlantic coast of Nova Scotia (Canada): Little Duck Island $\left(44^{\circ} 22^{\prime} \mathrm{N}, 64^{\circ} 11^{\prime} \mathrm{W}\right)$, off an exposed headland at the mouth of Mahone Bay, and Mill Cove $\left(44^{\circ} 35^{\prime} \mathrm{N}\right.$, $64^{\circ} 3^{\prime} \mathrm{W}$ ) in St. Margarets Bay, a large semi-protected bay (Fig. 1). At each site, the study area ranged from 5 to $10 \mathrm{~m}$ depth (Chart Datum). The substratum consists of basaltic ledges and troughs at Little Duck Island and granitic boulders and bedrock outcrops at Mill Cove. At the onset of the study in the summer of 1992, a dense aggregation (or front) of sea urchins Strongylocentrotus droebachiensis was moving onshore at each site, destructively grazing luxuriant kelp beds that extended throughout the study area and creating barrens in its wake. The kelp bed at Little Duck Island was comprised mainly of Saccharina longicruris (formerly Laminaria longicruris); other kelp species, Laminaria digitata and Alaria esculenta, were rare at sampled depths but more common in shallower water. The kelp bed at Mill Cove was comprised almost exclusively of $S$. longicruris. Blades of $S$. longicruris at Little Duck Island were smaller and narrower with less crenulated edges than those at Mill Cove, a pattern consistent with phenotypic plasticity of this species in response to differences in flow (Gerard \& Mann 1979). Membranipora membranacea was observed on $S$. longicruris at both sites throughout the study (Scheibling et al. 1999). For a detailed description of the sites, and structure and dynamics of the kelp bed assemblage, see Scheibling et al. (1999). 


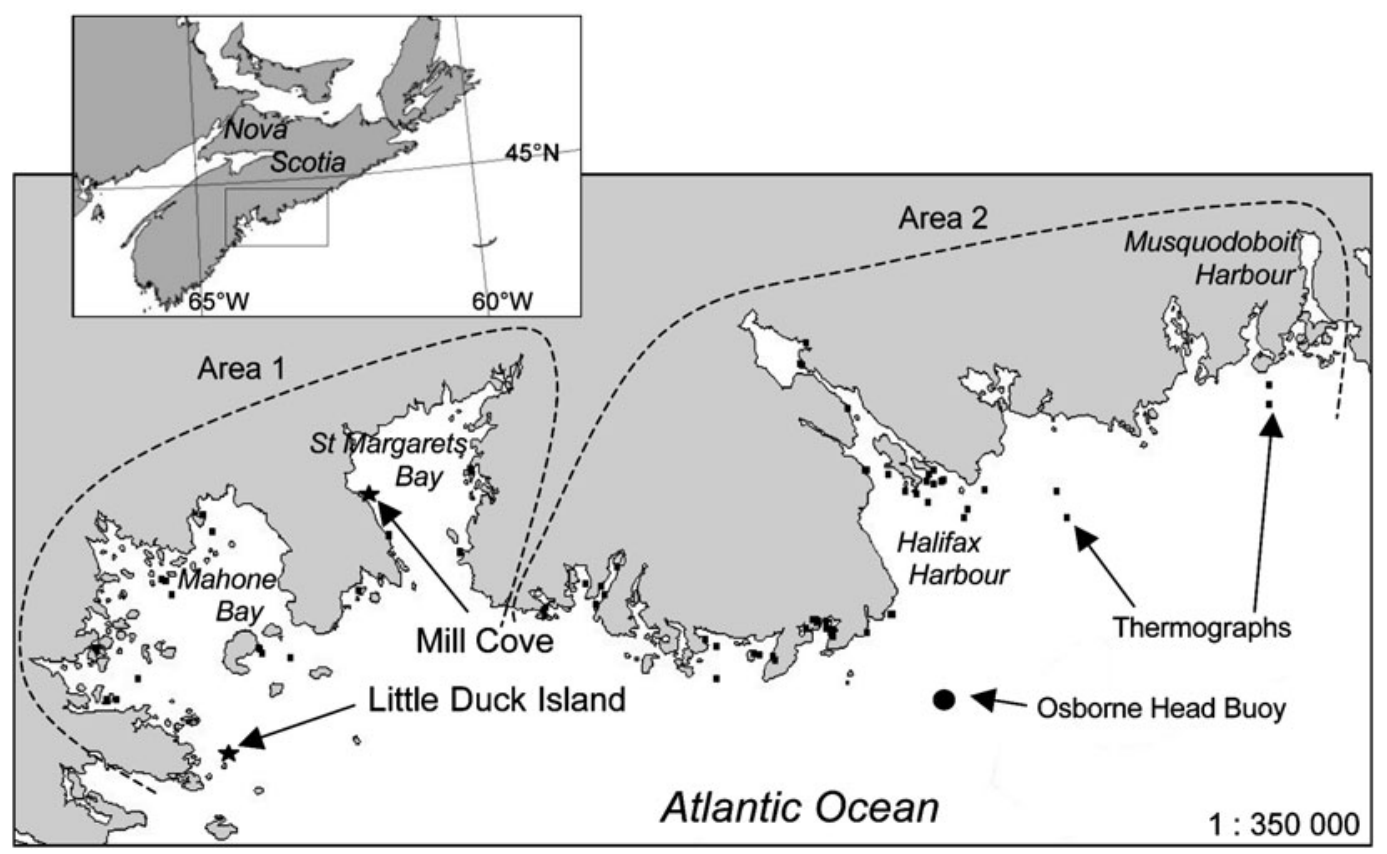

Fig. 1. Map of the central Atlantic coast of Nova Scotia showing the location of the study sites at Little Duck Island (Mahone Bay) and Mill Cove (St. Margarets Bay), and the position of thermographs (-) and the Osborne Head Buoy used to construct thermal and wave height histories for the period from 1991 to 2001. Thermographs were grouped in 2 geographical regions, Area 1 (Mahone Bay and St. Margarets Bay) and Area 2 (between St. Margarets Bay and Musquodoboit Harbour). See Appendix 1 for detailed analysis of temperature anomaly data

Bryozoan and kelp cover. The cover of Membranipora membranacea and kelp, and the density and blade size of kelp, were measured along 1 or 2 transects that extended $50 \mathrm{~m}$ alongshore at each site, in conjunction with other studies of community dynamics (Scheibling et al. 1999, Scheibling \& Gagnon 2006). Initially, a single transect was located within the kelp bed at $\sim 6 \mathrm{~m}$ depth and 5 to $10 \mathrm{~m}$ from the deeper edge of the bed (and urchin front). The transect location at each site was progressively shifted shoreward in September/October 1993 and July/August 1994 to maintain the same distance from the edge as the front advanced and consumed the kelp (see maps in Scheibling et al. 1999). Following recurrent outbreaks of disease that eliminated urchins at both sites in 1995 (Scheibling \& Hennigar 1997), sampling was terminated at Mill Cove and the location of the $6 \mathrm{~m}$ transect at Little Duck Island was staggered by $\sim 4 \mathrm{~m}$ (alongbottom distance) in successive years to preclude overlap of sampling areas. In 1997, a second transect was located at $\sim 8 \mathrm{~m}$ depth at Little Duck Island within a mixed algal assemblage (mainly Saccharina longicruris and Codium fragile) that had re-colonized the seabed after the urchin die-off. Transects were sampled 1 or 2 times per year in summer/fall (between June and November) over 11 yr (1992 to 1995, 1997 to 2002) at Little Duck Island and 4 yr (1992 to 1995) at Mill Cove.
To measure the percentage cover of Membranipora membranacea on kelp and of kelp on the bottom, we video-recorded a $1 \mathrm{~m}$ belt along a $50 \mathrm{~m}$ transect (delineated by weighted nylon line, graduated at $1 \mathrm{~m}$ intervals) using a diver-operated camera (Sony CCD-V801 Hi-8 video camera recorder in an Amphibico housing). A $1 \mathrm{~m}$ wide framer attached to the camera housing was used to keep the camera $0.6 \mathrm{~m}$ above the kelp canopy (or seabed) and centered on the transect line. The transect video data were augmented by archival video records that were routinely acquired, using the same camera system, during a series of studies at these sites (Scheibling \& Hennigar 1997, Meidel \& Scheibling 1998, Scheibling et al. 1999, Balch \& Scheibling 2000, Scheibling \& Gagnon 2006). These supplementary video records were reviewed to select clips for which the camera was perpendicular to the substratum and with adequate resolution to distinguish individual colonies of $M$. membranacea on kelp. The video records were transferred to a digital tape using a digital camcorder (Sony DCRVX 2000) and displayed on a high-resolution monitor (Sony Trinitron CPD-G520P). For each video record, 7 to 34 non-overlapping frames were randomly selected using iMovie and converted to JPEG file format for image analysis using Scion Image v. 1.63. For each frame, kelp cover and colonies of M. membranacea on kelp were digitally traced and the total areas of each were computed, to obtain the percentage 
cover of kelp on the bottom and the percentage cover of M. membranacea on kelp.

To measure kelp density and blade area of Saccharina longicruris, we manually collected kelps in 5 randomly positioned $1 \mathrm{~m}^{2}$ quadrats along a $50 \mathrm{~m}$ transect at each site. Individual thalli in each quadrat were counted and measured (total length, blade length and mid-point width). A blade area index was calculated for each quadrat as the sum of individual blade areas (length $\times$ width) divided by the sample area $\left(1 \mathrm{~m}^{2}\right)$.

Temperature and wave height. To examine relationships between physical oceanographic factors and changes in the cover of Membranipora membranacea and kelp, we constructed decadal histories (1991 to 2001) of sea temperature and wave height, applicable to our study sites, using oceanographic databases available from the Department of Fisheries and Oceans Canada (DFO). Temperature records were acquired from the Coastal Time Series (CTS) database (www. mar.dfo-mpo.gc.ca/science/ocean/data base/Doc2003/cts2003app.html). A thermal history (for the sampled depth range at our sites) was constructed from daily average temperature records from 188 thermographs recording at $\leq 10 \mathrm{~m}$ depth. We initially constructed a thermal history based on 55 thermographs located within Mahone Bay and St. Margarets Bay (our study area), but found some gaps in the record. To fill the gaps, we used data from an additional 133 thermographs located east of Mahone Bay (data were scarce west of St. Margarets Bay). Temperature records from this supplementary series were comparable to those from our initial series for days in common (Appendix 1, Fig. A1). Therefore, daily averages from the supplementary thermographs were substituted for missing data in the initial series. Each daily average in the composite temperature series was based on data from 2 to 15 thermographs. The most distant thermographs were $91 \mathrm{~km}$ apart (Fig. 1).

Wave data were obtained from the Integrated Science Data Management (ISDM) database (www.meds-sdmm. dfo-mpo.gc.ca/isdm-gdsi/index-eng.html) for the Osborne Head Buoy (OHB, MEDS037) located $45 \mathrm{~km}$ E-SE of Mill Cove, 76 km E-NE of Little Duck Island, and $5 \mathrm{~km}$ offshore $\left(44^{\circ} 29^{\prime} \mathrm{N}, 63^{\circ} 25^{\prime} \mathrm{W}\right)$ (Fig. 1). Aside from its proximity to both sites, OHB also was selected because it had a similar exposure to offshore swell as Little Duck Island. We used significant wave height (SWH), defined as the average height of the highest one-third of the waves in a wave field (calculated and broadcasted every $30 \mathrm{~min}$ by the buoy), as an index of wave energy. Output of a numerical model for ocean surface waves (WaveWatch-III) was used to supplement SWH data at OHB, which contained substantial gaps in 1999, 2000 , and 2001 (the last year of operation of OHB) (Appendix 2, Fig. A2).
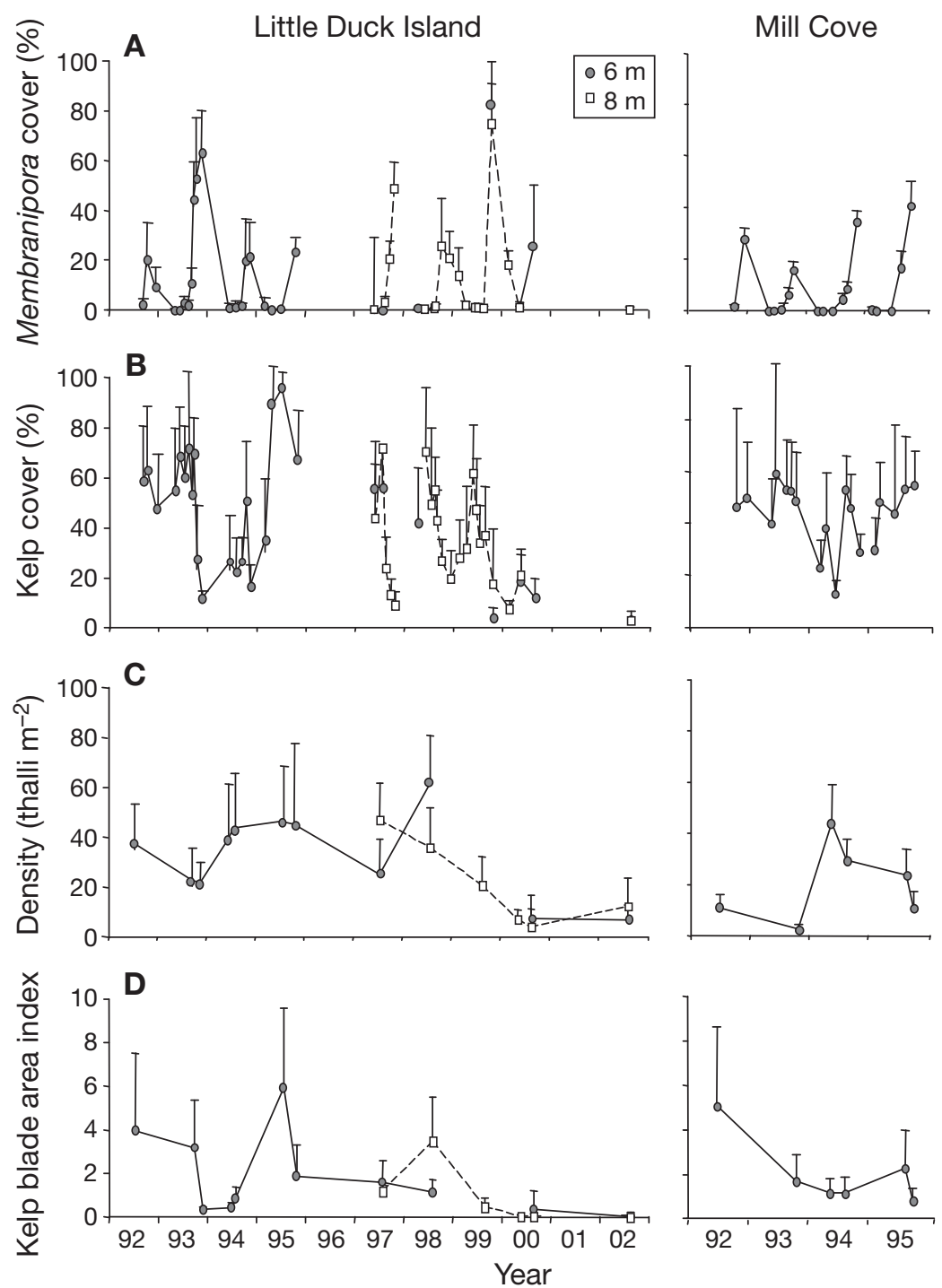

Fig. 2. Membranipora membranacea, Saccharina longicruris. Change in: (A) percentage cover of $M$. membranacea on kelp, (B) percentage cover of kelp on the bottom, (C) kelp density, and (D) kelp blade area index, at 6 and $8 \mathrm{~m}$ depths between September 1992 and August 2002 at Little Duck Island and at $6 \mathrm{~m}$ depth between June 1992 and October 1995 at Mill Cove. Data are mean +SD for 4 to 34 (at 6 m) and 5 to 15 (at $8 \mathrm{~m}$ ) replicate $1 \mathrm{~m}^{2}$ plots per sampling date at Little Duck Island and 4 to 10 replicate $1 \mathrm{~m}^{2}$ plots per sampling date at Mill Cove 
To determine whether interannual variation in the peak cover of Membranipora membranacea was related to sea temperature during the period of summer/ fall colony growth, we calculated a time-integrated thermal integral, $\mathrm{TI}_{\mathrm{w}}\left({ }^{\circ} \mathrm{D}\right)$, for the 3 mo warm period (August through October) prior to the peak in cover of the bryozoan, from 1992 to 1994 and 1997 to $1999 . \mathrm{TI}_{\mathrm{w}}$ was calculated as the sum of the daily average temperature over this period. We excluded 1995, because the peak was poorly resolved due to infrequent sampling, and 2000 to 2002, because the kelp bed had been decimated. To determine whether interannual variation in the peak cover of $M$. membranacea was related to sea temperature during the preceding period of cool and rising temperatures in winter/spring (which may affect colony survival, growth, and reproduction; Saunders \& Metaxas 2007), we calculated a thermal integral, $\mathrm{TI}_{\mathrm{C}^{\prime}}$ for the 6 mo cool period (January through June) of each year, from 1992 to 1994 and 1997 to 1999. We also calculated an annual thermal integral, $\mathrm{TI}_{\mathrm{a}}$, for each year between 1992 and 1999.

To determine whether interannual variation in the loss of kelp cover (calculated as the difference between the maximum and minimum percent cover between June and November) was related to wave conditions following the peak in cover of Membranipora membranacea, we delineated the top 10th percentile of daily averages of SWH during a 2 mo period when wave height was increasing (October and November), from 1992 to 1995 and 1997 and 1999. Wave data were not available during this period in 1998, and we excluded 2000 to 2002 for the reason mentioned above. We used simple linear regression to examine the relationships between the annual peak in bryozoan cover and our measures of thermal integral $\left(\mathrm{TI}_{\mathrm{w}}\right.$ or $\left.\mathrm{TI}_{\mathrm{c}}\right)$, and between the annual loss of kelp cover and the mean of the 10th percentile of $\mathrm{SWH}$, the maximum SWH, or the number of days for which SWH exceeded $1 \mathrm{SD}$ of the long-term (1991 to 2001) mean. We fitted a reciprocal function to the relationship between annual loss of kelp cover and peak bryozoan cover or $\mathrm{TI}_{\mathrm{W}}$ in the same year. We also examined the relationship between annual loss of kelp cover and peak bryozoan cover and $\mathrm{TI}_{\mathrm{w}}$ combined using stepwise multiple linear regression, with $\alpha=0.250$ to enter and $\alpha=0.1$ to remove an explanatory variable.

\section{RESULTS}

Seasonal and interannual variation in bryozoan cover: effects on kelp abundance and population structure

At both of our study sites, the cover of Membranipora membranacea on kelp exhibited a pronounced sea- sonal cycle each year, with a rapid increase in summer/fall (August to November) followed by a decline over winter to virtually non-detectable levels by early spring (April/May) (Fig. 2). At Little Duck Island, where we sampled over an $11 \mathrm{yr}$ period, there were significant interannual differences in the peak cover of M. membranacea (ANOVA, data pooled from 6 and $\left.8 \mathrm{~m}, F_{7,106}=33.5, \mathrm{p}<0.001\right)$. The most severe outbreaks were in 1993 and 1999, based on recorded peaks of 63 and $79 \%$, respectively, which did not differ significantly from one another (Tukey's honestly significant difference [HSD] test, $\mathrm{p}=0.15)$. The third highest peak in cover in 1997 (49\%) was similar to that in 1993 ( $\mathrm{p}=$ 0.39), but significantly lower than the peak in 1999 ( $\mathrm{p}<$ 0.001). At Mill Cove, there were too few observations to accurately assess interannual variation in the peak cover of $M$. membranacea.

Seasonal patterns of kelp cover on the seabed and bryozoan cover on kelp varied inversely at each site, with the greatest reciprocal changes occurring during severe outbreaks of Membranipora membranacea in 1993, 1997, and 1999 (Fig. 2). At Little Duck Island, the decrease in kelp cover between June and November 1992 to 1994 and 1997 to 1999 was significantly related to the peak cover of $M$. membranacea (reciprocal transformation) during this period $\left(\mathrm{R}^{2}=0.725, \mathrm{p}=\right.$ 0.031; Fig. 3). There was no significant relationship between the decrease in kelp cover and our thermal integral $\left(\mathrm{TI}_{\mathrm{w}}\right)$ during this period $\left(\mathrm{R}^{2}=0.545, \mathrm{p}=0.094\right)$, and $\mathrm{TI}_{\mathrm{w}}$ was not retained in a stepwise multiple regression model with peak bryozoan cover and $\mathrm{TI}_{\mathrm{w}}$ as explanatory variables. Between June 1992 and December 1993, the decrease in kelp cover (from $72 \%$ in August to $12 \%$ in November 1993) was associated with

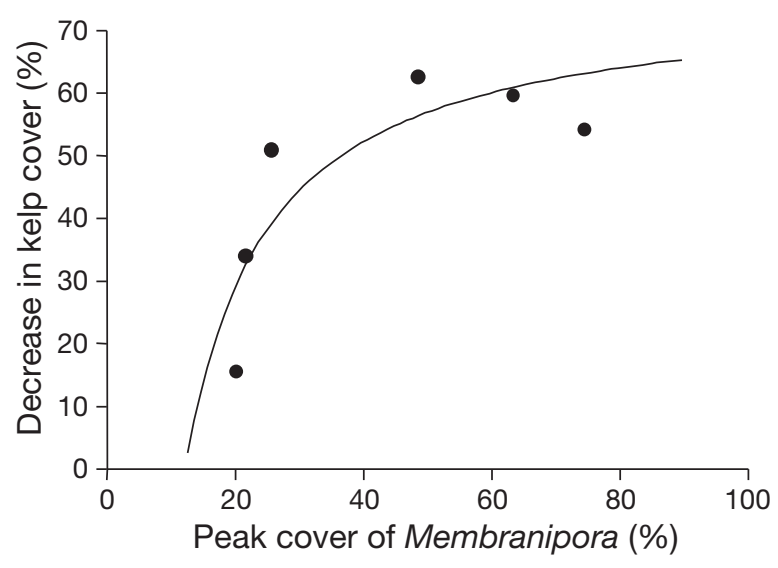

Fig. 3. Membranipora membranacea, Saccharina longicruris. Relationship between the decrease in cover of kelp $S$. longicruris and peak cover of $M$. membranacea on kelp during summer/fall (between June and November, 1992 to 1994 and 1997 to 1999). The curve is a reciprocal function fit to these data: $y=75.518-954.23(1 / x)$ 


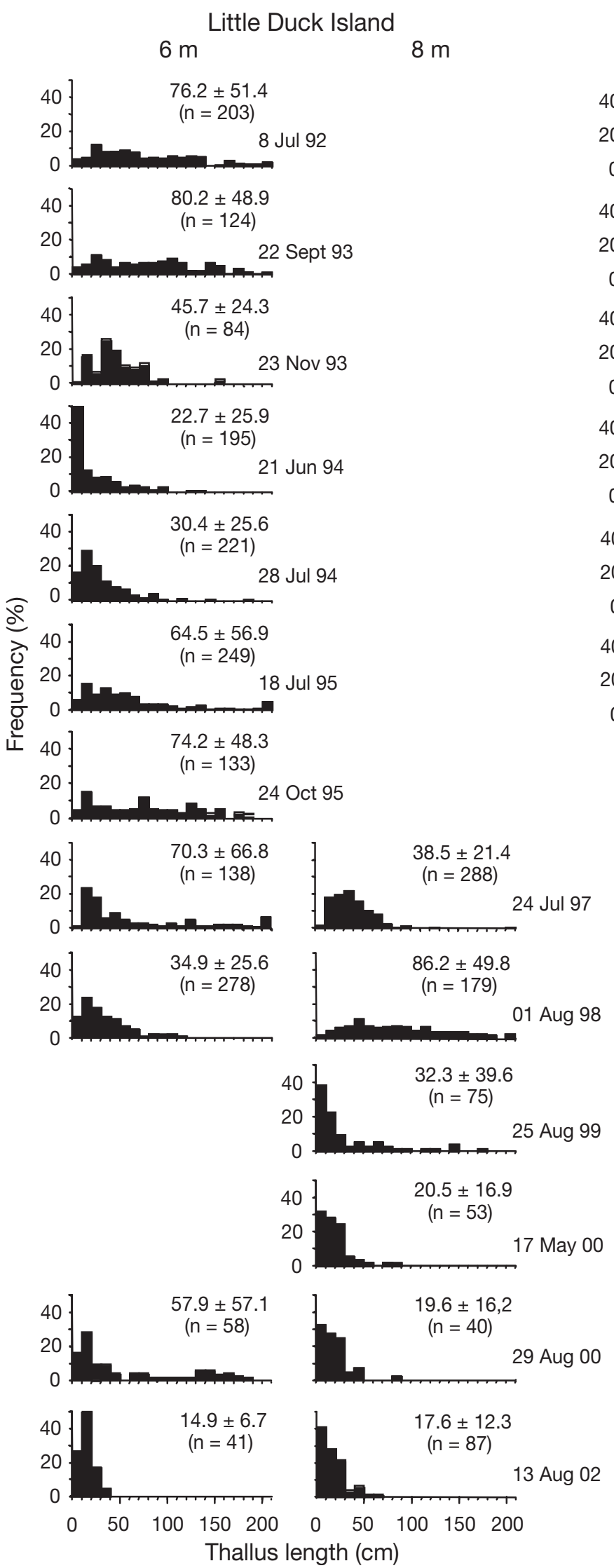

\section{Mill Cove}

$6 \mathrm{~m}$
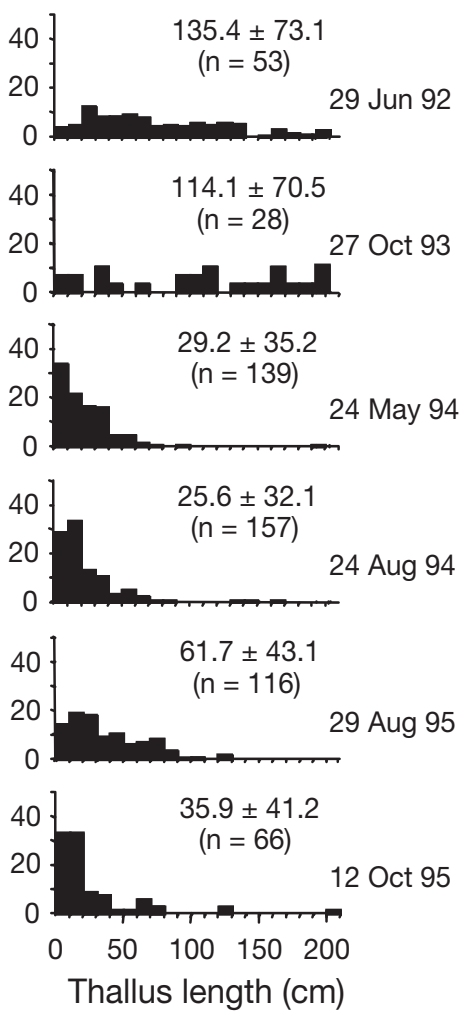

Fig. 4. Saccharina longicruris. Size-frequency distributions of kelp at 6 and $8 \mathrm{~m}$ depths between July 1992 and August 2002 at Little Duck Island and at $6 \mathrm{~m}$ depth between June 1992 and October 1995 at Mill Cove. Data are mean $\pm \mathrm{SD}$. $\mathrm{n}$ : sample size

$\sim 50 \%$ reduction in kelp density (from 38 to 20 thalli $\mathrm{m}^{-2}$ ) and an order of magnitude decrease in blade area index (from 4 to 0.5). Similar reductions in density (from 11 to 3 thalli $\mathrm{m}^{-2}$ ) and blade area index (from 5 to 1.7) were recorded at Mill Cove over that period (Fig. 2). Size-frequency distributions at both sites showed a broad range in thallus length (up to $\sim 200 \mathrm{~cm}$ ) between June/July 1992 and September/October 1993, but became highly skewed with the loss of large $(>50 \mathrm{~cm})$ thalli and the establishment of new recruits $(<10 \mathrm{~cm})$ by May/June 1994 (Fig. 4). This recruitment event at each site was reflected by sharp increases in kelp density in 1994 to levels that approximated or exceeded densities prior to the 1993 bryozoan outbreak, and an increase in blade area in 1995 as recruits grew larger (Fig. 2). At Little Duck Island, the growth of recruits and surviving thalli resulted in a broad size distribution by October 1995 (Fig. 4).

Following the 1993 defoliation event, kelp cover progressively increased over the next $2 \mathrm{yr}$, while the cover of Membranipora membranacea on kelp remained relatively low, although minor reductions in kelp cover were coincident with seasonal peaks in bryozoan abundance in these years. By summer/fall 
1995, kelp cover had rebounded to pre-defoliation levels (50 to $60 \%$ at Mill Cove) or higher (up to $94 \%$ at Little Duck Island, July 1995). At Little Duck Island, sampling was resumed in May 1997 (primarily at $8 \mathrm{~m}$ depth) after an 18 mo sampling interruption. The outbreak of $M$. membranacea in the fall of 1997 was again associated with a sharp decrease in kelp cover (from 75 to $9 \%$ at $8 \mathrm{~m}$ ), comparable to that observed in 1993 (Fig. 2). And again, the kelp bed recovered from defoliation during the following year, as indicated by increases in cover and a broad size distribution at $8 \mathrm{~m}$ (Figs. $2 \& 4$ ).

Although the cover of Membranipora membranacea on kelp at Little Duck Island was moderate in 1998, with a recorded peak of $26 \%$ in October, kelp cover decreased substantially and smaller thalli again dominated the bed by August 1999 (Figs. 2 \& 4). Another major outbreak of $M$. membranacea in 1999, with a peak cover of $74 \%$ in October, led to further decimation of the kelp bed. By 2000, kelp cover, density, and blade area index were reduced to minimal levels and the kelp population was mainly comprised of small thalli $(<50 \mathrm{~cm})$; there was no evidence of recovery up to the end of the study in August 2002 (Figs. 2 \& 4).

\section{Interannual variation in temperature and wave height: effects on bryozoan and kelp cover}

Sea temperature and wave height exhibited marked seasonal variation in the study area between 1991 and 2001 (Fig. 5). Temperature peaked in late summer (August/September; maximum monthly mean, $15.5^{\circ} \mathrm{C}$ ) and was coldest in late winter (February/March; minimum monthly mean, $0.6^{\circ} \mathrm{C}$ ). SWH was lowest in summer (June to August; minimum monthly mean, $0.7 \mathrm{~m}$ ), increased in fall and winter (September to December; maximum monthly mean, $2.6 \mathrm{~m}$ ), and remained high until spring (March/April), when it decreased again.

Cover of Membranipora membranacea increased with sea temperature in late summer to a fall peak in October/November. Interannual variation in peak cover of $M$. membranacea was significantly related $\left(\mathrm{R}^{2}=0.831, \mathrm{p}=0.011\right)$ to the thermal integral $\left(\mathrm{TI}_{\mathrm{w}}\right)$ calculated over the previous 3 mo period (August through October) during the periods from 1992 to 1994 and 1997 to 1999 (Fig. 6). There was no relationship between the thermal integral $\left(\mathrm{TI}_{\mathrm{C}}\right)$ calculated over the first 6 mo of each year and peak cover of M. membranacea for the same years $\left(\mathrm{R}^{2}=0.0002, \mathrm{p}=0.978\right)$. The annual thermal integral $\left(\mathrm{TI}_{\mathrm{a}}\right)$ showed a linear
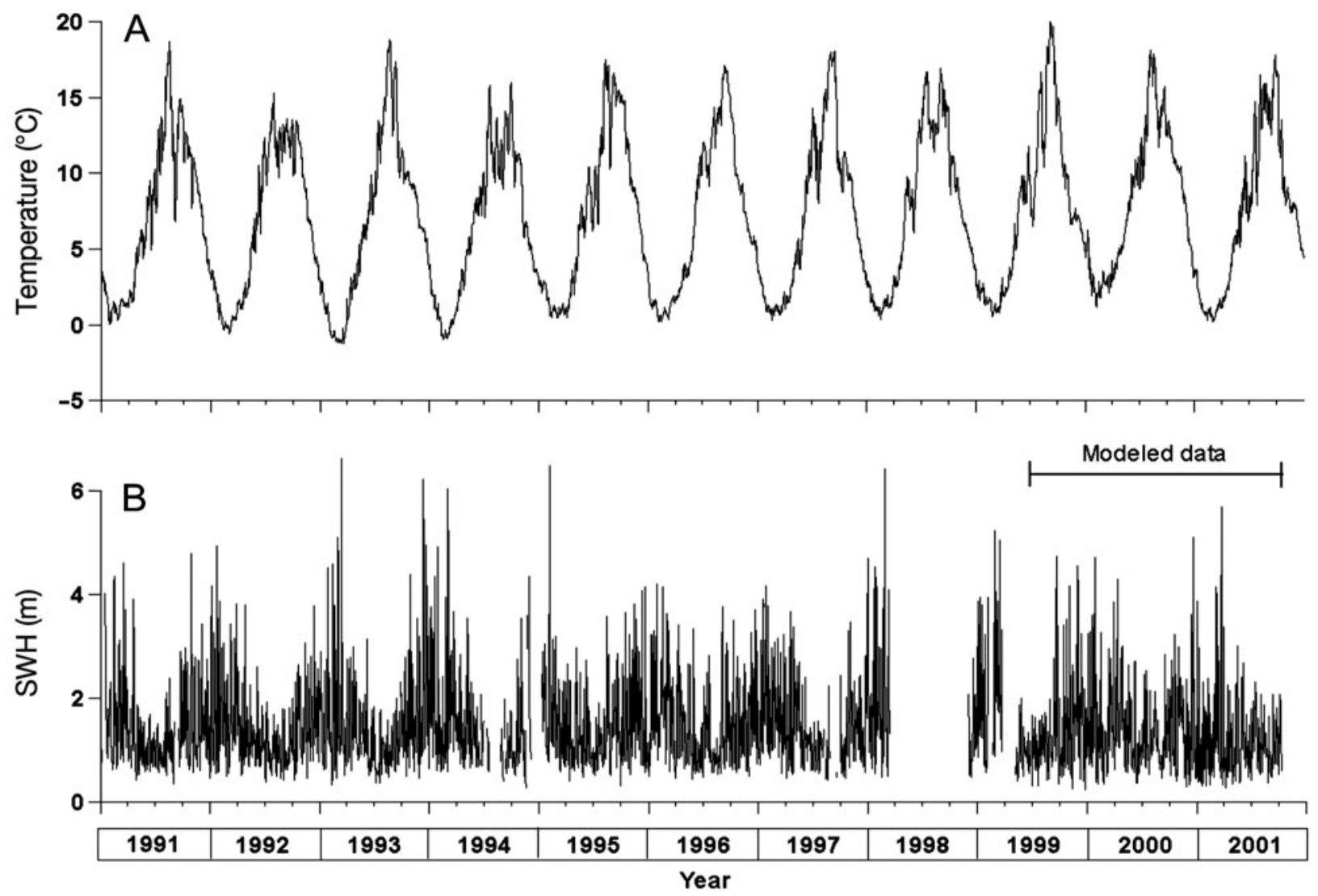

Fig. 5. Daily averages of: (A) sea temperature (<10 m depths) and (B) significant wave height (SWH) in the study area between 1991 and 2001 


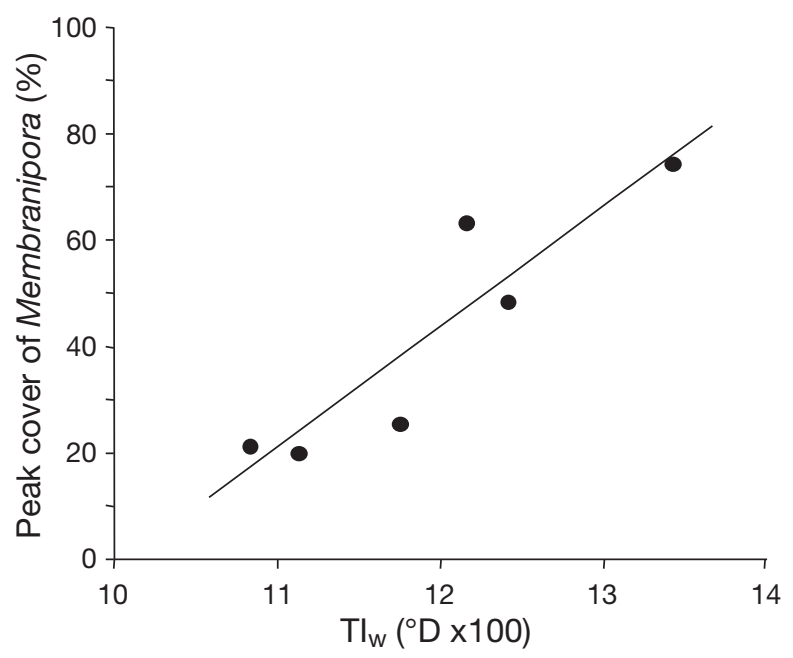

Fig. 6. Membranipora membranacea. Relationship between peak cover of $M$. membranacea on kelp and thermal integral $\left(\mathrm{TI}_{\mathrm{w}},{ }^{\circ} \mathrm{D}\right)$ measured over the previous 3 mo period (August to October, 1992 to 1994 and 1997 to 1999). The line is the linear fit to these data: $y=22.687 x-228.53$

increase between 1992 and $1999\left(R^{2}=0.720, p=0.008\right)$, ranging from $2322^{\circ} \mathrm{D}(1994)$ to $2783^{\circ} \mathrm{D}(1998)$.

The mean of the top 10th percentile $(n=6)$ of the average daily SWH in October and November each year ranged from $2.6 \mathrm{~m}$ (1992) to $3.5 \mathrm{~m}$ (1995), and the maximum ranged from $3.1 \mathrm{~m}$ (1992) to $4.4 \mathrm{~m}$ (1993). The number of days during this period when the average daily SWH exceeded 1 SD of the long-term (1991 to 2001 ) mean (mean $+\mathrm{SD}=2.25 \mathrm{~m}, \mathrm{n}=3569$ ) ranged from 7 (1997) to 18 (1995). There was no significant relationship between the decrease in kelp cover by the end of each year and any of these measures (mean of the 10th percentile: $\mathrm{R}^{2}=0.111, \mathrm{p}=0.519$; maximum: $\mathrm{R}^{2}=0.199, \mathrm{p}=0.375$; number of days exceeding $1 \mathrm{SD}$ : $\left.\mathrm{R}^{2}=0.164, \mathrm{p}=0.426\right)$. Because the break in sampling in October 1995 may have resulted in an underestimate of kelp loss in that year (when the duration of high waves and average SWH was greatest), we reanalyzed the data without 1995, but did not detect any significant relationships ( $p>0.20$ in all cases).

\section{DISCUSSION}

\section{Effects of bryozoan outbreaks on kelp bed structure and community dynamics}

Our study documents the devastating effects recurrent outbreaks of the invasive bryozoan Membranipora membranacea have had on the structure and abundance of native kelp populations along the coast of Nova Scotia. The cover of kelp on the seabed varied inversely with the cover of $M$. membranacea on kelp at
2 sites, with the greatest reciprocal changes in 1993, 1997, and 1999, when outbreaks of M. membranacea, and concomitant defoliation of kelp, were most severe. This pattern, along with other measures of kelp size and abundance that declined following bryozoan outbreaks, demonstrate both seasonal and cumulative impacts of $M$. membranacea on native kelp populations on a decadal scale.

The invasive green alga Codium fragile was introduced to the Atlantic coast of Nova Scotia by 1989 (Bird et al. 1993), around the time of introduction of Membranipora membranacea (both likely were transported from the Gulf of Maine). Experimental studies have shown that $C$. fragile can competitively displace kelps and other native seaweeds through opportunistic exploitation of disturbance-generated gaps within kelp beds, such as those created by M. membranacea (Levin et al. 2002, Scheibling \& Gagnon 2006). Once established as dense meadows, $C$. fragile prevents re-colonization by kelp and persists as the dominant canopy-forming seaweed for years (Watanabe, Scheibling \& Metaxas, unpubl. data). Although the abundance (cover and density) and size of kelp at Little Duck Island decreased sharply following severe outbreaks of M. membranacea in 1993 and 1995, these measures returned to pre-defoliation levels within $2 \mathrm{yr}$, before $C$. fragile was established at this site. After the outbreak in 1999, however, the kelp bed showed no signs of recovery throughout the remainder of the study. The loss of kelp in 1999 coincided with the development of a dense meadow of C. fragile in 1999 and 2000 (Chapman et al. 2002), which inhibited recruitment and recovery of kelps and other native macroalgae (Scheibling \& Gagnon 2006).

Laminarian kelps grow best during winter months when nutrients are readily available, and erosion of blades increases in the fall when nutrients become depleted (Gagné et al. 1982). Infestation of kelp by Membranipora membranacea may accelerate erosion and fragmentation by altering the biomechanical properties of the blades (Dixon et al. 1981, Scheibling et al. 1999). Bryozoan crusts also reduce rates of nutrient uptake and photosynthesis (Cancino et al. 1987, Hurd et al. 2000) and block spore release (Saier \& Chapman 2004). We found the extent of kelp loss in a given year was relatively low when the cover of $M$. membranacea was $<25 \%$, but reached the highest levels (decreases of kelp cover ranging from 55 to $65 \%$ ) when bryozoan cover was $>50 \%$, indicating low resilience of kelps to moderate and severe infestations of $M$. membranacea. At these times, colonies of $M$. membranacea can overgrow the entire thallus and breakage at the base of the blade results in loss of the meristematic region, precluding blade regeneration (Fig. 7). The residual stipe subsequently rots, resulting in major declines in kelp density and biomass (Scheibling et al. 1999). 


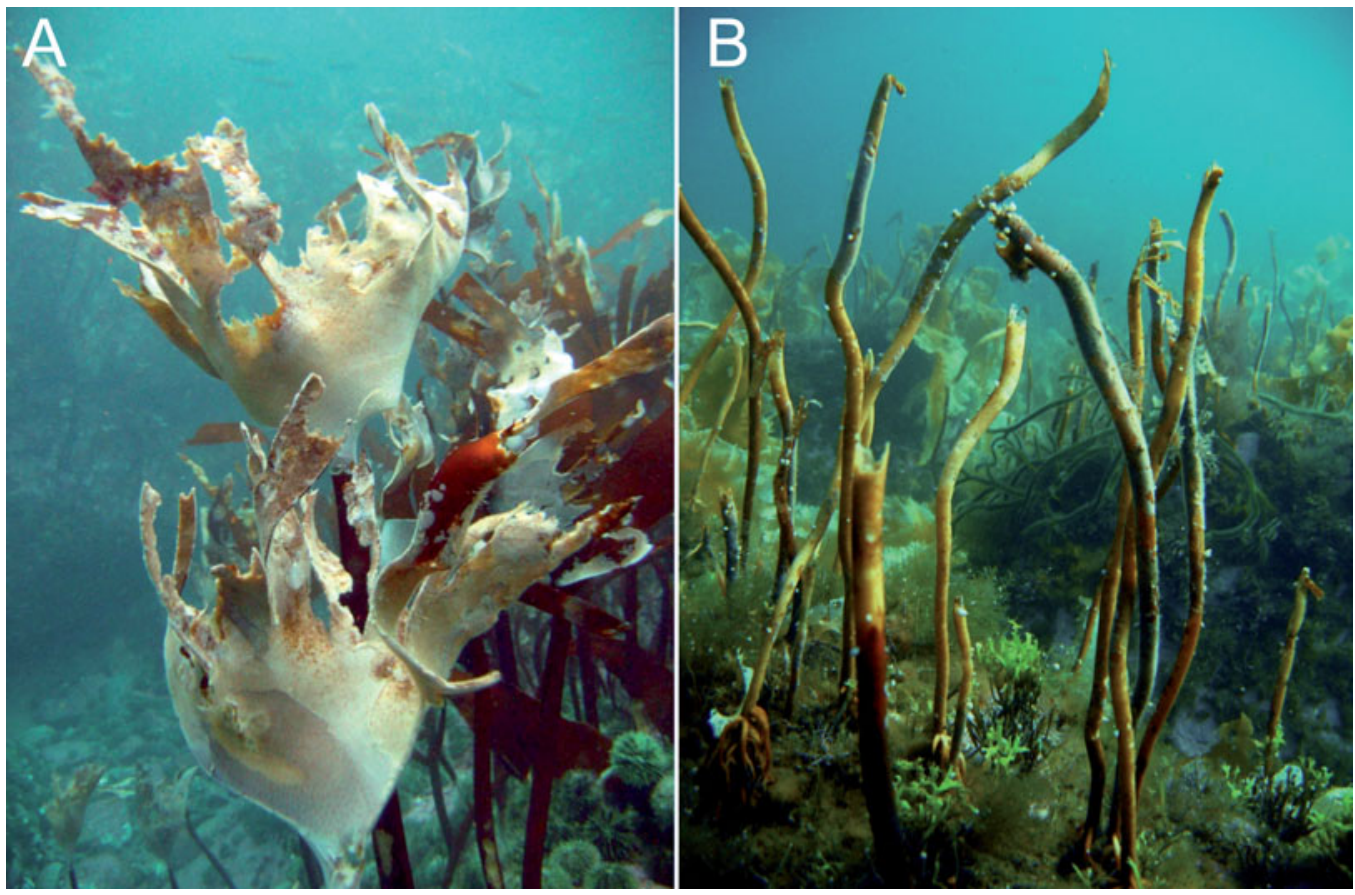

Fig. 7. Membranipora membranacea. (A) Heavily encrusted thallus of Laminaria digitata with M. membranacea completely covering the meristem and greatly eroded blades. (B) Residual stipes of Saccharina longicruris after complete loss of blades following a major bryozoan outbreak. Photographs by R. E. Scheibling

At Little Duck Island, annual decreases in kelp cover in the summer/fall were strongly related to the peak cover of Membranipora membranacea during this period. Although in regression analyses we did not detect a significant relationship between the decrease in kelp cover and thermal integral $\left(\mathrm{TI}_{\mathrm{W}}\right)$, this does not preclude the possibility that temperature per se, or some other environmental variable associated with temperature (e.g. nutrient availability), directly affects the biomechanical properties of kelp blades that influence erosion rate. Simple regression indicates that peak bryozoan cover is a better predictor of interannual variation in kelp loss than the thermal integral, and colinearity of these explanatory variables supports exclusion of the latter in a multiple regression model. Further research is required to elucidate relationships between the erosion rate of kelp, cover of $M$. membranacea, and environmental variables, both on an individual and population basis. Biomechanical analyses also are needed to provide a mechanistic understanding of these relationships.

The destructive potential of Membranipora membranacea adds to that of sea urchin fronts that intensively graze kelp beds at rates of up to $4 \mathrm{~m} \mathrm{mo}^{-1}$ (Scheibling et al. 1999, Gagnon et al. 2004, LauzonGuay \& Scheibling 2007). Unlike urchin fronts, which form along the lower margin of kelp beds, M. membranacea occurs throughout the beds, although the abundance of colonies may increase with depth (Saunders \& Metaxas 2008). The loss of kelp biomass associated with severe outbreaks of $M$. membranacea likely exceeds that by urchin grazing, in both rate and extent. On the Atlantic coast of Nova Scotia, urchin populations undergo episodic mass mortalities caused by outbreaks of the pathogenic amoeba Paramoeba invadens (Scheibling 1986, 1988). Urchin fronts were decimated by $P$. invadens in 1993 and 1995, which arrested destructive grazing and enabled kelp recovery following outbreaks of $M$. membranacea in each year (Scheibling et al. 1999, Chapman et al. 2002). In the absence of disease, urchin populations likely would consume defoliated kelp beds at an increased rate (Lauzon-Guay \& Scheibling 2007). Interestingly, $P$. invadens also may be an alien species repeatedly introduced to the coast of Nova Scotia by large-scale oceanographic or meteorologic features (Scheibling \& Hennigar 1997). Thus, the capacity of kelps to regenerate following outbreaks of $M$. membranacea appears context dependent, being higher during years of concurrent outbreaks of $P$. invadens and lower in areas invaded by Codium fragile.

Loss of kelp canopy caused by Membranipora membranacea encrustation, and the attendant replacement of kelp beds by meadows of Codium fragile, have profound effects on habitat structure and benthic community organization (Harris \& Tyrell 2001, Chapman 
et al. 2002, Levin et al. 2002). Schmidt \& Scheibling $(2006,2007)$ documented changes in the abundance of mobile macrofauna, epibiota, and turf algae associated with experimental reduction in canopy cover, and a shift from kelp to $C$. fragile dominance. Also, a large proportion of kelp production enters food webs as drift algae that is consumed by detritivores (e.g. urchins in barrens) or particulate organic matter that is degraded by microbes and consumed by deposit- and suspension-feeding invertebrates (Duggins et al. 1989, Norderhaug et al. 2003, Page et al. 2008). Thus, increased production of kelp detritus during outbreaks of $M$. membranacea in the shallow subtidal zone also affects energy flow to adjacent ecosystems in deeper waters.

\section{Sea temperature, wave energy, and the severity of bryozoan outbreaks}

In Nova Scotia, Saunders \& Metaxas (2008) found that the thermal integral during the winter and spring preceding the reproductive period of Membranipora membranacea, accounted for up to $81 \%$ of variability in settlement of the bryozoan on kelp, and that juvenile colonies occurred earlier and were an order of magnitude more abundant following the warmer of 2 successive winters. Based on these observations, they hypothesized that peak cover of $M$. membranacea in summer and fall was directly related to their measure of thermal integral (Saunders \& Metaxas 2007, 2008). Our decadal time-series at Little Duck Island does not support this hypothesis. We found a strong positive relationship between peak cover of $M$. membranacea in fall and the thermal integral $\left(\mathrm{TI}_{\mathrm{w}}\right)$ calculated over a 3 mo period preceding the peak, but no relationship when the thermal integral $\left(\mathrm{TI}_{\mathrm{c}}\right)$ was calculated over the first 6 mo of the year. Therefore, we propose that warm sea temperature in late summer and fall, by accelerating colony growth of M. membranacea on kelp blades, is the key determinant of the severity of bryozoan outbreaks, rather than winter and spring temperatures that affect the timing and rate of recruitment. Laboratory and field studies have shown that growth of $M$. membranacea, both within the native range (Menon 1972) and in Nova Scotia (Saunders \& Metaxas in press), is directly related to temperature between 6 and $18^{\circ} \mathrm{C}$. The annual thermal integral $\left(\mathrm{TI}_{\mathrm{a}}\right)$ increased continuously between 1992 and 1999 along the coast of Nova Scotia, suggesting that global phenomena affecting ocean climate can affect the severity of bryozoan outbreaks and, thus, the frequency and magnitude of kelp loss and associated community shifts.

Sessile marine organisms in coastal areas are exposed to drag, lift, and acceleration forces caused by currents and waves (Denny 1988). These forces play a critical role in the organization of marine communities in intertidal and shallow subtidal habitats along wave-exposed coasts (Denny \& Wethey 2001, Witman \& Dayton 2001). Kelps, with their remarkable flexibility, are particularly well adapted to withstand high wave energies (Koehl 1982, Dayton 1985). However, their resistance to waveinduced breakage may be weakened when blades are encrusted with Membranipora membranacea (Dixon et al. 1981). Interestingly, we found no relationship between the decrease in kelp cover following outbreaks of M. membranacea and 3 indices of wave energy (based on SWH), suggesting that erosion of bryozoan-encrusted blades was not strongly affected by wave forces. This conclusion must be viewed with caution however, as the spatial and temporal scales of our study may have been too coarse to detect effects of wave action that operate on individual thalli over periods of weeks to months. This underscores the importance of conducting studies over a range of spatial and temporal scales to elucidate patterns and processes of invasion, and the associated changes in native populations and communities. Long-term observational studies, in particular, are needed to validate and refine predictive models of species invasions and their ecological consequences, and to assess the influence of ocean climate on these phenomena.

Acknowledgements. We thank A. Hennigar, T. Balch, I. Dempsey, and A. Shaw for help with fieldwork, R. Melady and O. D'Amours for image analysis, and D. Lyons for assistance with statistical analysis. We also thank B. Petrie for guidance on extraction and analysis of sea temperature and wave data, and R. Mulligan for modeling of wave data. We thank M. Saunders and A. Metaxas for helpful comments on the manuscript. This research was supported by a Natural Sciences and Engineering Research Council of Canada (NSERC) Discovery Grant to R.E.S.

\section{LITERATURE CITED}

Balch T, Scheibling RE (2000) Temporal and spatial variability in settlement and recruitment of echinoderms in kelp beds and barrens in Nova Scotia. Mar Ecol Prog Ser 205: 139-154

Bax N, Williamson A, Aguero M, Gonzalez E, Geeves W (2003) Marine invasive alien species: a threat to global biodiversity. Mar Policy 27:313-323

Berman J, Harris L, Lambert W, Buttrick M, Dufresne M (1992) Recent invasions of the Gulf of Maine: three contrasting ecological histories. Conserv Biol 6:435-441

Bird CJ, Dadswell MJ, Grund DW (1993) First record of the potential nuisance alga Codium fragile ssp. tomentosoides (Chlorophyta, Caulerpales) in Atlantic Canada. Proc NS Inst Sci 40:11-17

> Bruno JF, Kennedy CW, Rand TA, Grant MB (2004) Landscape-scale patterns of biological invasions in shoreline plant communities. Oikos 107:531-540

Cancino JM, Munoz J, Orellana MC (1987) Effects of the bryozoan Membranipora tuberculata (Bosc.) on the photosynthesis and growth of Gelidium rex Santelices and Abbot. J Exp Mar Biol Ecol 113:105-112 
Carlton JT (1996) Marine bioinvasions: the alteration of marine ecosystems by non-indigenous species. Oceanography 9:36-43

Carlton JT (1999) Scale and ecological consequences of biological invasions in the world's oceans. In: Sandlund OT, Schei PJ, Viken A (eds) Invasive species and biodiversity management. Kluwer, Dordrecht, p 195-212

Carlton JT, Geller JB (1993) Ecological roulette: the global transport of nonindigenous marine organisms. Science 261:78-82

Chapman AS, Scheibling RE, Chapman ARO (2002) Species introductions and changes in marine vegetation of Atlantic Canada. In: Claudi R, Nantel P, Muckle-Jeffs E (eds) Alien invaders in Canada's waters, wetlands and forests. Natural Resources Canada, Canadian Forest Service Science Branch, Ottawa, p 133-148

Dayton PK (1985) Ecology of kelp communities. Annu Rev Ecol Syst 16:215-245

Denny MW (1988) Biology and the mechanics of the waveswept environment. Princeton University Press, Princeton

Denny M, Wethey D (2001) Physical processes that generate patterns in marine communities. In: Bertness MD, Gaines SD, Hay ME (eds) Marine community ecology. Sinauer Associates, Sunderland, MA, p 3-37

Dixon J, Schroeter SC, Kastendiek J (1981) Effects of the encrusting bryozoan, Membranipora membranacea, on the loss of blades and fronds by the giant kelp, Macrocystis pyrifera (Laminariales). J Phycol 17:341-345

> Duggins DO, Simenstad CA, Estes JA (1989) Magnification of secondary production by kelp detritus in coastal marine ecosystems. Science 245:170-173

> Gagné JA, Mann KH, Chapman ARO (1982) Seasonal patterns of growth and storage in Laminaria longicruris in relation to differing patterns of availability of nitrogen in the water. Mar Biol 69:91-101

Gagnon P, Himmelman JH, Johnson LE (2004) Temporal variation in community interfaces: kelp-bed boundary dynamics adjacent to persistent urchin barrens. Mar Biol 144:1191-1203

Gerard VA, Mann KH (1979) Growth and production of Laminaria longicruris (Phaeophyta) populations exposed to different intensities of water movement. J Phycol 15:33-41

Harris LG, Tyrell MC (2001) Changing community states in the Gulf of Maine: synergism between invaders, overfishing and climate change. Biol Invasions 3:9-21

Hurd CL, Durante KM, Harrison PJ (2000) Influence of bryozoan colonization on the physiology of the kelp Macrocystis integrifolia (Laminariales, Phaeophyta) from nitrogenrich and -poor sites in Barkley Sound, British Columbia. Phycologia 39:435-440

Koehl MAR (1982) The interaction of moving water and sessile organisms. Sci Am 247:124-134

> Lambert WJ, Levin PS, Berman J (1992) Changes in the structure of a New England (USA) kelp bed: the effects of an introduced species? Mar Ecol Prog Ser 88:303-307

Lauzon-Guay JS, Scheibling RE (2007) Seasonal variation in movement, aggregation and destructive grazing of the green sea urchin (Strongylocentrotus droebachiensis) in relation to wave action and sea temperature. Mar Biol 151:2109-2118

Lauzon-Guay JS, Scheibling RE, Barbeau MA (2009) Modelling phase shifts in a rocky subtidal ecosystem. Mar Ecol Prog Ser 375:25-39

Levin PS, Coyer JA, Petrik R, Good TP (2002) Communitywide effects of nonindigenous species on temperate rocky reefs. Ecology 83:3182-3193

Meidel SK, Scheibling RE (1998) Annual reproductive cycle of the green sea urchin, Strongylocentrotus droebachiensis, in differing habitats in Nova Scotia, Canada. Mar Biol 131: 461-478

Menon NR (1972) Heat tolerance, growth and regeneration time in three North Sea bryozoans exposed to different constant temperatures. Mar Biol 15:1-11

> Miller RJ (1985) Succession in sea urchin and seaweed abundance in Nova Scotia, Canada. Mar Biol 84:275-286

> Norderhaug KM, Fredriksen S, Nygaard K (2003) Trophic importance of Laminaria hyperborea to kelp forest consumers and the importance of bacterial degradation to food quality. Mar Ecol Prog Ser 255:135-144

Page HM, Reed DC, Brzezinski MA, Melack JM, Dugan JE (2008) Assessing the importance of land and marine sources of organic matter to kelp forest food webs. Mar Ecol Prog Ser 360:47-62

Provan J, Booth D, Todd NP, Beatty GE, Maggs CA (2008) Tracking biological invasions in space and time: elucidating the invasive history of the green alga Codium fragile using old DNA. Diversity Distrib 14:343-354

Pysek P, Richardson DM, Pergl J, Jarosik V, Sixtova Z, Weber E (2008) Geographical and taxonomic biases in invasion ecology. Trends Ecol Evol 23:237-244

Ruiz GM, Fofonoff PW, Carlton JT, Wonham MJ, Hines AH (2000) Invasion of coastal marine communities in North America: apparent patterns, processes, and biases. Annu Rev Ecol Syst 31:481-531

Saier B, Chapman AS (2004) Crusts of the alien bryozoan Membranipora membranacea can negatively impact spore output from native kelps (Laminaria longicruris). Bot Mar 47:265-271

Saunders M, Metaxas A (2007) Temperature explains settlement patterns of the introduced bryozoan Membranipora membranacea in Nova Scotia, Canada. Mar Ecol Prog Ser 344:95-106

Saunders M, Metaxas A (2008) High recruitment of the introduced bryozoan Membranipora membranacea is associated with kelp bed defoliation in Nova Scotia, Canada. Mar Ecol Prog Ser 369:139-151

Saunders M, Metaxas A (in press) Effects of temperature, size, and food on the growth of Membranipora membranacea in laboratory and field studies. Mar Biol

Scheibling RE (1986) Increased macroalgal abundance following mass mortalities of sea urchins (Strongylocentrotus droebachiensis) along the Atlantic coast of Nova Scotia. Oecologia 68:186-198

Scheibling RE (1988) Microbial control of sea urchins: Achilles' heel or Pandora's box? In: Burke RD, Mladenov PV, Lambert P, Parsley RL (eds) Echinoderm biology. Balkema, Rotterdam, p 745-754

Scheibling RE, Gagnon P (2006) Competitive interactions between the invasive green alga Codium fragile ssp. tomentosoides and native canopy-forming seaweeds in Nova Scotia (Canada). Mar Ecol Prog Ser 325:1-14

Scheibling RE, Hennigar AW (1997) Recurrent outbreaks of disease in sea urchins Strongylocentrotus droebachiensis in Nova Scotia: evidence for a link with large-scale meteorologic and oceanographic events. Mar Ecol Prog Ser 152:155-165

Scheibling RE, Hennigar AW, Balch T (1999) Destructive grazing, epiphytism, and disease: the dynamics of sea urchin-kelp interactions in Nova Scotia. Can J Fish Aquat Sci 56:2300-2314

Schmidt AL, Scheibling RE (2006) A comparison of epifauna and epiphytes on native kelps (Laminaria spp. and the invasive green alga Codium fragile ssp. tomentosoides) in Nova Scotia, Canada. Bot Mar 49:315-330 
Schmidt AL, Scheibling RE (2007) Effects of native (Laminaria spp.) and invasive (Codium fragile ssp. tomentosoides) macroalgal canopies on composition and abundance of mobile benthic macrofauna and turf-forming algae. J Exp Mar Biol Ecol 341:110-130

Schwaninger HR (2008) Global mitochondrial DNA phylogeography and biogeographic history of the antitropically and longitudinally disjunct marine bryozoan Membranipora membranacea L. (Cheilostomata): Another cryptic marine sibling species complex? Mol Phylogenet Evol 49: 893-908

Stachowicz JJ, Byrnes JE (2006) Species diversity, invasion success, and ecosystem functioning: disentangling the influence of resource competition, facilitation, and extrinsic factors. Mar Ecol Prog Ser 311:251-262

Tolman HL (1991) A third-generation wave model for wind waves on slowing varying, unsteady and inhomogeneous depths and currents. J Phys Oceanogr 21:782-797

Tolman HL (2002) User manual and system documentation of WaveWatch-III, Version 2.22. Technical Note 222, NOAA/ NWS/NCEP/MMAB, Washington, DC

With KA (2002) The landscape ecology of invasive spread. Conserv Biol 16:1192-1203

Witman JD, Dayton PK (2001) Rocky subtidal communities. In: Bertness MD, Gaines SD, Hay ME (eds) Marine community ecology. Sinauer Associates, Sunderland, MA, p 339-366

Appendix 1. Analysis of temperature anomaly data

The correspondence between temperature data from 55 thermographs in Mahone Bay and St. Margarets Bay (Area 1, Fig. 1) and from an additional 133 thermographs located east of St. Margarets Bay (Area 2) was examined for days with common measurements between 1991 and 2001. The daily average water temperature between 1 January 1991 and 31 December 2001 was computed in each area. The average sea temperature for each calendar day was also computed in each area by averaging the daily average temperature values for a given calendar day throughout the 11 yr (1991 to 2001), providing a total of 366 data points in each area. The difference (anomaly) between the average temperature on a given day and the long-range (11 yr) average temperature for the corre- sponding calendar day was calculated for each area. The anomaly data within Areas 1 and 2 were plotted against each other (both are standardized values) over different temporal ranges (days, months, and years), and the resulting $\mathrm{R}^{2}$ statistic was used to assess the strength of the fit between the 2 datasets.

The timing and magnitude of changes in temperature anomalies were consistent between Areas 1 and 2, especially at the shortest temporal range (10s of days) used in this study $\left(\mathrm{R}^{2}=0.92, \mathrm{p}<0.0001\right.$; Fig. A1C). Given the high correspondence in the anomaly data between areas, temperature data from thermographs east of St. Margarets Bay were substituted for missing data from the record in Mahone Bay and St. Margarets Bay.
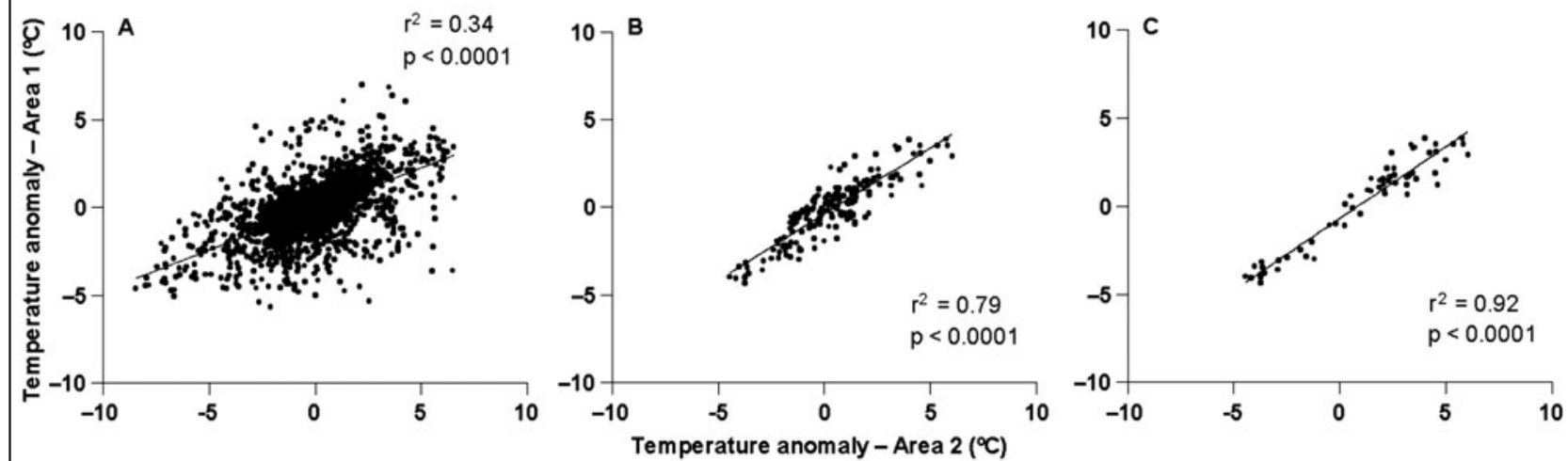

Fig. A1. Relationships between anomalies in daily average sea temperature from 55 thermographs in Area 1 (Mahone Bay and St. Margarets Bay) and 133 thermographs in Area 2 (east of St. Margarets Bay up to Musquodoboit Harbour; Fig. 1) over: (A) 2931 d between January 1991 and December 2001 (entire dataset); (B) 184 d between July and December 1993 (second half of the first of $3 \mathrm{yr}$ with most severe Membranipora membranacea infestations); and (C) $61 \mathrm{~d}$ in August and September 1993 (2 mo preceding the peak cover of $M$. membranacea on kelp) 
Appendix 2. Estimating of missing wave data

The WaveWatch-III model is a third generation ocean wave model that solves the spectral wave action density balance equation (Tolman 1991). The model is applicable to ocean basin scales outside nearshore areas, operating on the assumptions that the wave field varies over time and spatial scales that are much larger than individual waves and that shallow water wave processes are negligible. The physics of wave propagation, growth by wind, nonlinear interactions, dissipation due to whitecapping, and dissipation due to bottom friction are included in the model (Tolman 2002). The model has been applied to the western North Atlantic basin on a grid with a $0.25^{\circ}$ resolution by the U.S. National Oceanographic \& Atmospheric Administration (NOAA), using operational wind products over the basin from the U.S. National Centers for Environmental Prediction (NCEP) as input, and validated using buoy and satellite observations of winds and waves.

Significant wave height (SWH) simulated by the WaveWatch-III model was used to estimate wave conditions along the Atlantic coast of Nova Scotia. Hindcast model output in $3 \mathrm{~h}$ intervals was obtained from NOAA for the period from 1 July 1999 to 10 October 2001. Due to logistical constraints, the model could not be used to fill a $261 \mathrm{~d}$ gap from 15 March to 30 November 1998, or beyond 10 October 2001. The output SWH at Osborne Head Buoy (OHB) was selected, and daily average values were determined for comparison with model predictions. A scatter plot created for the $473 \mathrm{~d}$ with common measurements and model output at OHB showed a fairly consistent bias toward under$\mathrm{R}^{2}=0.72$ (Fig. A2). The wave model, driven by a global wind model, predicted the timing of wave events by including the prediction of the wave height, with a slope of $\beta=0.75$ and

necessary physics, directional resolution, and resolution in geographical space. However, the predicted SWH near Nova Scotia was often smaller than observations, with a mean difference of $0.32 \mathrm{~m}$, likely due to model limitations near the coast. To correct this, the model-predicted SWH at OHB were multiplied by $1 / \beta$, and the results used to complete the 445 missing days in the wave record in 1999, 2000, and 2001

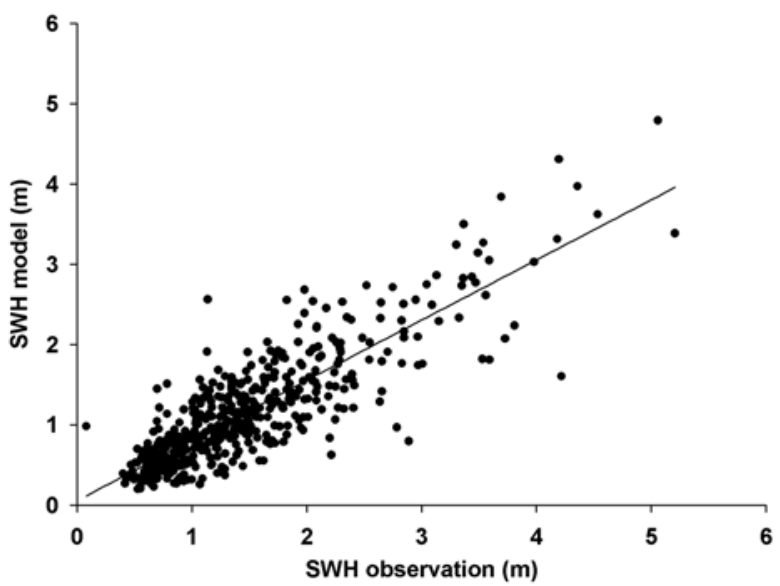

Fig. A2. Relationship between significant wave height (SWH) output, by numerical ocean wave model (WaveWatch-III), and daily average $\mathrm{SWH}$ from observations at Osborne Head Buoy $(\mathrm{n}=473)$

Editorial responsibility: Otto Kinne, Oldendorf/Luhe, Germany
Submitted: May 19, 2009; Accepted: July 6, 2009 Proofs received from author(s): August 20, 2009 